Acta Horticulturae et Regiotecturae 2

Nitra, Slovaca Universitas Agriculturae Nitriae, 2016, pp. 32-36

\title{
THE REGISTER SUGGESTIONS: PROCESSING TOOL FOR LAND CONSOLIDATION PROJECTS
}

\author{
Zlatica MUCHOVÁ*, Mária LEITMANOVÁ
}

Slovak University of Agriculture in Nitra, Slovak Republic

\begin{abstract}
Article presents The register SUGGESTIONS, what is one of the main part of the OKTOPUS system (System about land, creation and land consolidation in Slovakia). This system has been created and presented in the model catchment area of the river Žitava in the previous work (125 cadastral areas in total area of 162,801 ha). Optimal combinations of land management are described mainly for land consolidation projects from erosion control, water management and ecological perspective. Modified processes for calculating the degree of soil erosion risk of the area, coefficient of ecological stability and methods of determination of critical points are used in The register SUGGESTIONS. Based on identified and evaluated dominant problems in the area there are proposed solutions (through symbols derived from concrete situations on land blocks) where to aim potential suggestions, mainly for designers of land consolidation projects. The contribution states procedures of obtaining symbols of The register SUGGESTIONS, recommendations derived from the register and three case studies.
\end{abstract}

Keywords: The register SUGGESTION, OKTOPUS system, land consolidation, processing tool

Land consolidation (LC) is the most positive intervention in the agricultural country which solves organization and comprehensive protection of country. This opinion is shared by scientist from Slovakia, Czechia (e.g. Dumbrovský, 2004; Sklenička, 2006) but also from abroad (e.g. Hartvigsen, 2014; Vitikainen, 2004). Conducting of LC closely relates with pursuing of Rural Recovery Programme, which effectively motivates residents of municipalities by own strive for the development of environment, conservation of natural and cultural values of municipalities. Importance of LC can be specified from different perspectives. Importance of LC for plot owners and plot users underlines e.g. Jürgenson et al. (2010) mainly in the possibility of plot consolidation, in the modification of plot shape and in the real possibility of the division of co-ownership. Tarasovičová et al. (2013) and others underline concept in papers how LC can help to increase the market value of the land, opportunities to start using their land and transparent bargain of new rental contracts for accurately measured plots. Importance of LC for municipalities underlines e.g. Vašek (2014) in clarification of ownership relations to the land, in the transfer of majority of the land under the proposed common facilities to municipal property, leading to simplification of their future implementation. Significant benefit of LC is the implementation of elements of common facilities from state resources or the EU funds, which pass into the property of the municipality. According to Korthals and Bong (2011), the benefit of LC is to make available land by creating a network of field and forest roads and by reducing the movement of agricultural technology inside municipality as a result of their implementation. E.g. Pašakarnis and Maliene (2010) highlight the issue of comprehensively constructed field roads in relation to regional development. Solution of a harmless diversion of surface water and the protection against flooding using realization of erosion control and water management measures is described by e.g. Šinka and Konc (2014). Druga and Faltan (2014) consider LC as a significant benefit to the increase of ecological stability and diversity of the surrounding countryside as a result of planting local elements of territorial system of ecological stability. Simplification and reduction of precession of municipal plan, specification of certain elements according to the current municipal plan to the level of individual plots, new arrangement of accessible land are the main topics of authors Korthals and Bong (2011).

Practice has shown that with few exceptions, areas of land consolidation projects are dealt with separately. Interconnection with neighboring cadastral areas is not taken into account. Solution of flood protection and erosion control is addressed incorrectly, only inside the cadastral area. The need drawn out from the facts is to develop a comprehensive system of analysis needed for proper direction or decision.

The aim of this contribution is to interpret a part of the OKTOPUS system - the register SUGGESTIONS as a tool for projecting land consolidation project in terms of solutions to water erosion, critical points in the country and ecological stability. 


\section{Material and methods}

\section{About the OKTOPUS system}

The base of the OKTOPUS system (Leitmanová, 2013) is all available collected graphical information about the area of interest, georeferenced in datum of Uniform Trigonometric Cadastral Network (S-JTSK). The whole catalogue of information of OKTOPUS system is derived into 4 themes (Figure 1A). Basic thematic backgrounds are divided into registers (7) (Figure 1B). Issue of each register is reflected in the union register with name The register SUGGESTIONS. The OKTOPUS system has been processed into book of maps from author Leitmanová (2013) in the form of themes and registers.

\section{Model area}

The OKTOPUS system, processing tool in projection of land consolidation projects, has been processed in the contribution from author Muchová et al. (2016) in the model catchment area of the river Žitava. The district Nitra, Zlaté Moravce, Nové Zámky, Komárno as parts of the Nitra region and the district Žarnovica as a part of the Banská Bystrica region interfere into the catchment area. In the catchment area there are located 125 cadastral areas with the whole area of 162,801 ha.

\section{Three selected processed issues of OKTOPUS system}

In the OKTOPUS system there were processed more areas related to landscaping according to Muchová et al. (2016). For the purpose of this article, we state three areas which a designer of land consolidation may use in projecting. The unit for calculating of water erosion of soil is the land unit.

\section{Water erosion of soil}

For detailed determination of the intensity of water erosion there is used the universal soil loss equation, which was edited for Slovak conditions by Janeček et al. (2012). The essence of erosion control protection is to reach an intensity of water erosion in the area less or equal to the acceptable erosion. General erosion control criteria defining erosion endangering land blocks were used for more detailed criteria. Endangerment of land blocks was defined on the basis of the combination of the land unit and slope size and slope length, which use for example Cross compliance,
Good Agricultural and Environmental Conditions GAEC (MZe, 2015).

\section{Critical points}

Based on the Methodology of flood risk mapping there were determined critical points (T.G.M. Water Research Institute, 2009). According to the listed methodology, the critical point occurs where drainage line, which has certain parameters, crosses the border of built-up area and enters into it.

\section{Ecological stability}

By modified calculation of ecological stability for LC purposes (Muchová et al., 2009) there were determined the basic principles of ecological and landscape planning of country. We have created the combination for erosion control and water management measures and derived the map from the coefficient of ecological stability. We have defined the need for any measures primarily to the development of green infrastructure of country.

\section{Results and discussion}

Partial result of the work by Leitmanová (2013) on the OKTOPUS system is The register SUGGESTIONS, part of which (water erosion, critical points, ecological stability) was used for post-processing of results. The article represents The register SUGGESTIONS as a tool for land consolidation processing. Scheme of process of the land consolidation project is shown in Figure 2. We used a combination of criteria in demonstrating the results that we have divided into logical sections: erosion, critical points and ecological stability of the territory.

\section{A/ Evaluation of soil erosion situation in a land unit}

Soils of model area were assigned to 5 classes of degree of soil erosion risk (DSER) based on calculations according to the conventional method DSER. Percentage representation of land falling within each class of DSER was calculated on model area. The percentages of the classes DSER were signs associated with land units. Table 1 presents all possible combinations derived from the real percentage of the classes DSER in land units for the model area.

According to the percentage of land falling to particular classes, DSER (symbol), assigning to land units in the model area can be stated that:

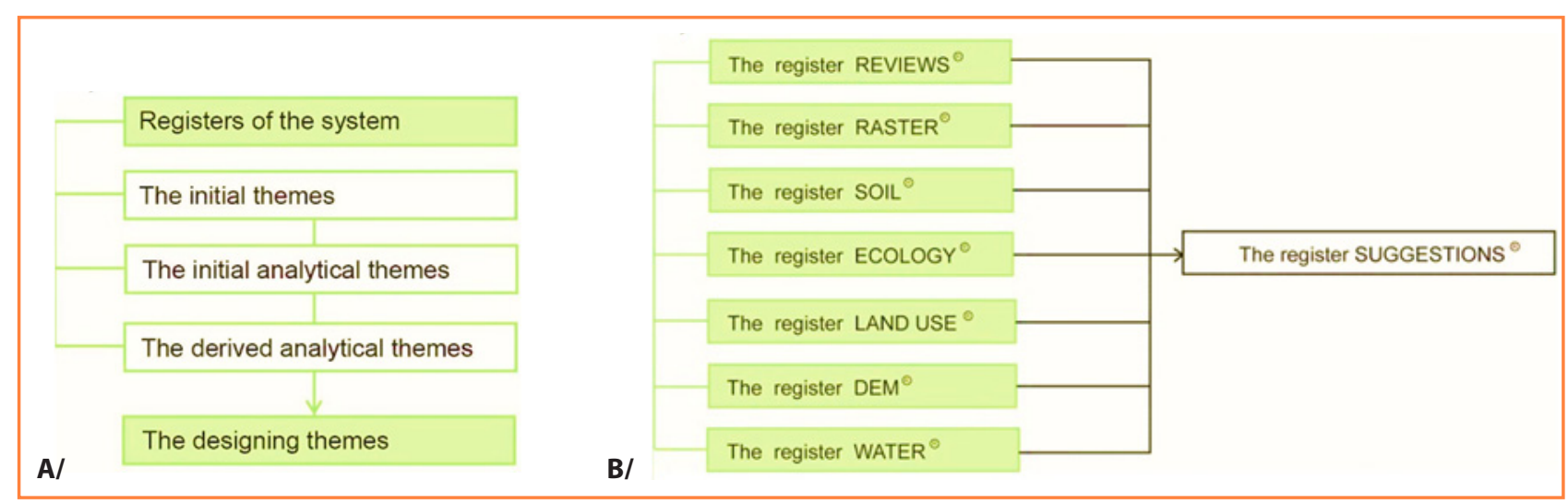

Figure 1 A/ Catalogue of thematic layers, B/ Map registers Source: Own draft 


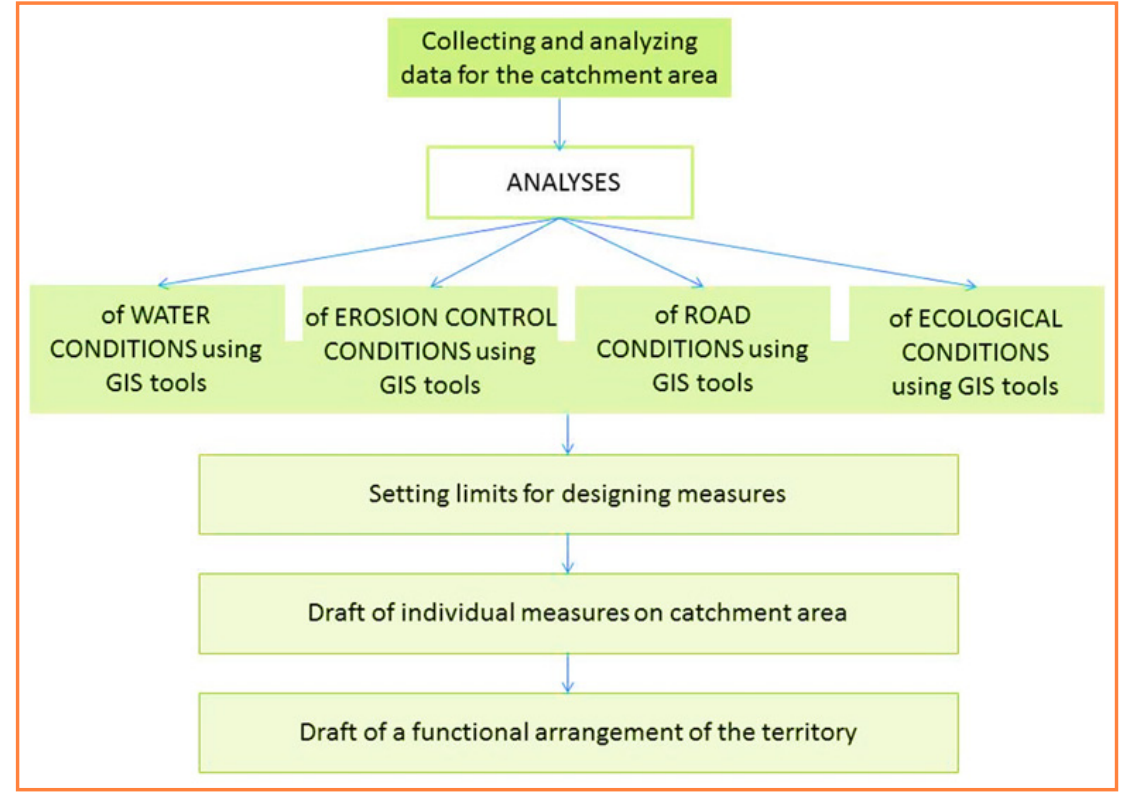

Figure 2 Scheme of process of land consolidation projects Source: Own draft
- symbol A1 a A2 - it is not necessary to deal with erosion control measures in the relevant land blocks,

- symbol A2/B2, A3/1, A3/2, F1, B1, B2, $B 3 / 1$ - medium erosion endangered land,

- symbol B2/C2, C1, C2, C3/1, E3/1, F2 significantly endangered land,

- symbol B3/2, C2/D2, C3/2, D3/1, D1, D2, D2/E2, D3/2, E1, E2, E3/2 - highly to catastrophically endangered land.

For processing of a LC project from the perspective of erosion control it can be stated, that it would be theoretically possible to exclude land units that are spatially placed in the first or second class of DSER (symbols A1, A2). However, upon closer inspection of land units, it was found that the subject units have a real problem with the appearance

Table 1 Percentage of classes DSER in one land unit and symbols derived thereof

\begin{tabular}{|c|c|c|c|c|c|}
\hline DSER1 & DSER 2 & DSER 3 & DSER 4 & DSER 5 & SYMBOL \\
\hline $95-100 \%$ & \multicolumn{4}{|c|}{$1-5 \%$} & $\mathrm{~A} 1$ \\
\hline $60-95 \%$ & \multicolumn{4}{|c|}{ \%DSER $2>\% D S E R ~ 3$ + \%DSER 4 + \%DSER 5} & $\mathrm{~A} 2$ \\
\hline $60-95 \%$ & \multicolumn{4}{|c|}{ \%DSER $2<\%$ DSER 3 + \%DSER 4 + \%DSER 5} & A2/B2 \\
\hline $40-60 \%$ & \multicolumn{4}{|c|}{ \%DSER $2>\%$ DSER $3+\%$ DSER 4 + \%DSER 5} & $\mathrm{~A} 3 / 1$ \\
\hline $40-60 \%$ & \multicolumn{4}{|c|}{$\%$ DSER $2<\%$ DSER 3 + \%DSER 4 + \%DSER 5} & $\mathrm{~A} 3 / 2$ \\
\hline \multicolumn{5}{|c|}{ \%DSER 1 + \%DSER 2 > \%DSER 3 + \%DSER4 + \%DSER 5} & F1 \\
\hline $1-5 \% a$ & $95-100 \%$ & $1-5 \% \mathrm{~b}$ & B1 & & \\
\hline \%DSER 1 & $60-95 \%$ & 0 & 0 & 0 & B2 \\
\hline \%DSER 1 & \%DSER 2 & $60-95 \%$ & $\%$ DSER 4 & \%DSER 5 & $\mathrm{~B} 2 / \mathrm{C} 2$ \\
\hline \%DSER 1 & $40-60 \%$ & \multicolumn{3}{|c|}{ \%DSER 1 > \%DSER 3 + \%DSER 4 + \%DSER 5} & $\mathrm{~B} 3 / 1$ \\
\hline \%DSER 1 & $40-60 \%$ & \multicolumn{3}{|c|}{ \%DSER $1<\%$ DSER 3 + \%DSER 4 + \%DSER 5} & $\mathrm{~B} 3 / 2$ \\
\hline $1-5 \% a$ & $95-100 \%$ & $1-5 \% \mathrm{~b}$ & $\mathrm{C} 1$ & & \\
\hline \%DSER 1 & 0 & $60-95 \%$ & 0 & 0 & $\mathrm{C} 2$ \\
\hline \%DSER 1 & \%DSER 2 & \%DSER 3 & $60-100 \%$ & \%DSER 5 & $\mathrm{C} 2 / \mathrm{D} 2$ \\
\hline \%DSER 1 & \%DSER 2 & $40-60 \%$ & \multicolumn{2}{|c|}{ \%DSER $1+\%$ DSER $2>\%$ DSER 4 + \%DSER 5} & $\mathrm{C} 3 / 1$ \\
\hline \%DSER 1 & $\%$ DSER 2 & $40-60 \%$ & \multicolumn{2}{|c|}{$\%$ DSER 1 + \%DSER $2<\%$ DSER 4 + \% DSER 5} & $\mathrm{C} 3 / 2$ \\
\hline $1-5 \% a$ & $95-100 \%$ & $1-5 \% b$ & D1 & & \\
\hline \%DSER 1 & 0 & 0 & $60-95 \%$ & 0 & D2 \\
\hline $0-40 \%$ & $60-100 \%$ & D2/E2 & & & \\
\hline \multicolumn{3}{|c|}{$\%$ DSER $1+\%$ DSER $2>\%$ DSER $3+\%$ DSER 5} & $40-60 \%$ & \%DSER 5 & $\mathrm{D} 3 / 1$ \\
\hline \multicolumn{3}{|c|}{ \%DSER $1+\%$ DSER $2<\%$ DSER 3 + \%DSER 5} & $40-60 \%$ & $\%$ DSER 5 & $\mathrm{D} 3 / 2$ \\
\hline $1-5 \%$ & $95-100 \%$ & E1 & & & \\
\hline \%DSER 1 & 0 & 0 & 0 & $60-95 \%$ & E2 \\
\hline \multicolumn{4}{|c|}{ \%DSER 1 + \%DSER 2 > \%DSER 3 + \%DSER 4} & $40-60 \%$ & $\mathrm{E} 3 / 1$ \\
\hline \multicolumn{4}{|c|}{$\%$ DSER $1+\%$ DSER $2<\%$ DSER $3+\%$ DSER 4} & $40-60 \%$ & $\mathrm{E} 3 / 2$ \\
\hline \multicolumn{5}{|c|}{ \%DSER $1+\%$ DSER $2<\%$ DSER 3 + \%DSER 4 + \%DSER 5} & $\mathrm{~F} 2$ \\
\hline
\end{tabular}

Source: Own draft 
of surface erosion. And so additional criteria were included to the previous assessment, concretely the size criteria of land units, the average value of slope and drainage lines contained in the land unit by Cross compliance GAEC (MZe, 2012) and after that new symbols were derived - N1-1, N1-2, N1-3, N2-1, N2-2, N2-3:

- symbol N1-1 was defined if soil drainage length acquires the total length of over 600 meters, the slope is $<=3^{\circ}$ and plot size is up to 35 hectares, then we recommend the upper boundary protecting of land avoiding foreign inflow of water,

- symbol N1-2 was defined if soil drainage length acquires the total length of over 500 meters, the slope is between $3^{\circ}$ and $5^{\circ}$ and plot size is up to 35 hectares, then we recommend crop production in stripes,

- symbol N1-3 was defined if soil drainage length acquires the total length of over 400 meters, the slope is $>=5^{\circ}$ and plot size is up to 35 hectares, then we recommend exclusion of growing erosion-prone crops,

- symbol N2-1 was defined if soil drainage length acquires the total length of over 300 meters, the slope is $<=3^{\circ}$ and plot size is above 35 hectares, then we recommend grassland thalwegs (concentrated runoff), disrupting surface runoff terracing (linear runoff),

- symbol N2-2 was defined if soil drainage length acquires the total length of over 250 meters, the slope is between $3^{\circ}$ and $5^{\circ}$ and plot size is above 35 hectares, then we recommend crop production in stripes combined with permanent grassland,

- symbol N2-3 was defined if soil drainage length acquires the total length of over 200 meters, the slope is $>=5^{\circ}$ and plot size is above 35 hectares, then we recommend exclusion of growing erosion-prone crops, calculation of acceptable flow length and to take steps such as terracing and digging ditches.

Example: We consider symbol C3/2 in case of appearance of $40 \%$ area with slightly endangered soil in class DSER 3 and when bigger part of other area of soil is included in class DSER 4 a 5 . The land unit is included to the $\mathrm{C} 3 / 2$ symbol and we proceed on the base of flow length, average slope and area of land unit. Area of land unit is over $35 \mathrm{ha}$, value of flow length is over $200 \mathrm{~m}$ and the average slope of the area is $5^{\circ}$. It means that project engineer has to calculate acceptable flow length and based on acceptable flow length he/ she uses measures for interruption surface run off in the land unit.

\section{B/ Determination of critical points in the territory}

in terms of flood protection

The system for critical points determination (T.G.M. Water Research Institute, 2009; Dumbrovský at al., 2014) was processed based on runoff

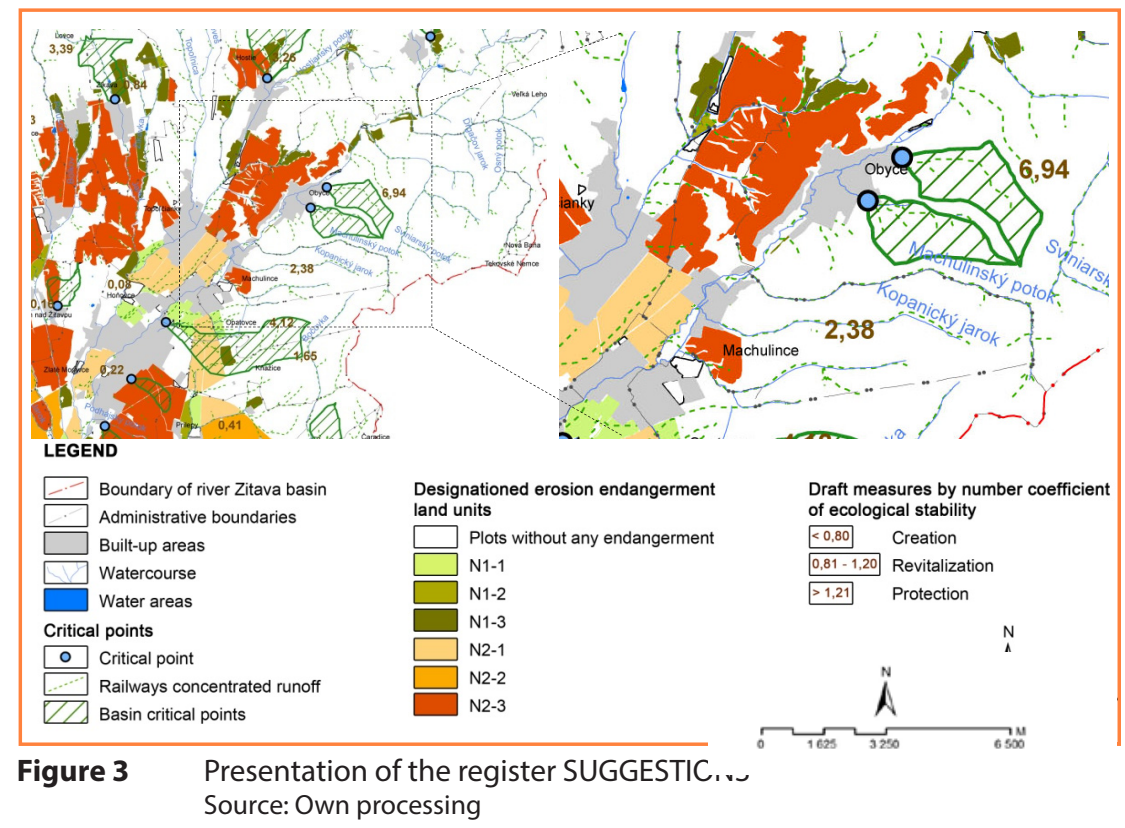

conditions and the area's topography at the point of water accumulation. The critical point is determined where the drainage line with contributing area $\geq 0.3 \mathrm{~km}^{2}$ encounters a build-up area. We take into account critical points whose accumulating area is not bigger than $10 \mathrm{~km}^{2}$, in terms of the areal extant of a causal phenomenon torrential rainfall and primary local result of subsequent floods. By subsequent procedure there are determined watershed lines and contributing areas of critical points. Orographic watershed and polygons of accumulating areas are generated in the geographic information system environment based on digital elevation model using hydrology tools.

Example: Two critical points were identified, land units with the symbol C3/2 mostly with forest land in the area. A project engineer must think about the management of catchment area of the critical point obviously in relation to measures on farmland. E.g. a project engineer should define the draft of stabilization of possible ravines, to consult drafts with forest manager and consider the possible location of the polder or dry protective basin at the above defined critical points.

\section{C) Evaluation of the need to direct any drafts more to green infrastructure than to purely technical measures and facilities on the basis of environmental quality of the area}

The need to lead measures to extended green infrastructure of country was defined by combination of draft need of erosion control and water management and derived map of the modified coefficient of ecological stability for LC purpose (Muchová et al., 2009). In case that the need to build new measures and facilities occurs in the area and the coefficient of ecological stability is low, a project engineer should clearly give priority to the construction of ecological friendly measures before technical measures. The practice points to the fact that the project engineer prefers the draft of technical measures prior to the natural friendly regardless the ecological stability mainly for reasons of smaller space requirements.

Example: Land units included in symbol C3/2, with very low ecological stability of the area, were identified. 
A project engineer should lead suggestions to natural friendly measures and e.g. to project depression terrace instead of dich, stabilize thalwegs by grassing etc.

The map of suggestions (Figure 3 ) provides a combination of information, as a processing tool by projecting of LC. From this tool the user of the system is able to detect, on the level of the cadastral area, which measures are recommended for certain land units.

\section{Conclusion}

The OKTOPUS system has been defined and filled model in order to provide information base about a model area. The OKTOPUS system is divided into registers based on thematic layers. Initial themes, initial analytical themes and derived analytical themes present thematic layer information to issues. The register SUGGESTIONS arose from appropriate combinations of themes. Based on it, it is possible to create or find information. It is also possible to define connections between two territories in models. A processing tool has been processed in form of resulting map based on The register SUGGESTIONS, the tool can help to design land consolidation projects by projecting. The register SUGGESTIONS has been created by combination of water erosion, critical points and ecological stability. Table DSER was created in terms of water erosion by processing The register SUGGESTIONS. As many as 26 symbols have been defined based on combinations of prevalence in DSER classes on land unit. After that we defined 6 new symbols in further evaluation of area. Suggestions were derived based on new symbols for activities taking place on land units. Because of better explanation of the use of The register SUGGESTIONS, we mentioned three examples with solutions (tool), which may occur in country and which may project managers solve in country. The OKTOPUS system and specifically its part The register SUGGESTIONS is also used for backward evaluation of area, if a project of land consolidation does not neglect drafts that would optimize the area.

\section{Acknowledgements}

The results obtained in the research projects VEGA no. $1 / 0673 / 16$ have been used in this paper.

\section{References}

DRUGA, M. - FALŤAN, V. 2014. Influences of environmental drivers on land cover structure and its long term changes: A case study of the villages of Malachov and Podkonice in Slovakia. In Moravian Geographical Reports, vol. 22, 2014, no. 3, pp. 29-41. doi:10.2478/ mgr-2014-0016.

DUMBROVSKÝ, M. 2004. Landscape Reform. $1^{\text {st }}$ ed., Brno : CERM, 2004, p. 250. ISBN 80-214-2668.

DUMBROVSKY, M. - SOBOTKOVA V. - ŠARAPATKA, B. - CHLUBNA L. - VACHALOVÁ, R. 2014. Cost-effectiveness evaluation of model design variants of broadbase terrace in soil erosion control. In Ecological Engineering, vol. 68, 2014, pp. 260-269.
HARTVIGSEN, M. 2014. Land reform and land fragmentation in Central and Eastern Europe. In Land Use Policy, vol. 36, 2014, pp. 330-341.

JANEČEK, M. -DOSTAL,T.-KOZLOVSKYDUFKOVÁ, J. - DUMBROVSKY, M. - HŮLA, J. - KADLEC, V. - KOVÁŘ, P. - KRÁSA, J. - KUBATOVÁ, E. KOBZOVÁ, D. - KUDRNACOVÁ, M. - NOVOTNY, I. - PODHRÁZKA, J. - PRAŽAN, J. - PROCHÁDZKOVÁ, E. - STŘEDOVA, H. - TOMAN, F. VOPRAVIL, J. - VLASAK, J. 2012. Protecting agricultural land from erosion, water erosion, wind erosion, soil conservation, surface runoff. Prague : The Czech University of Life Sciences, 2012. 113 p. ISBN 978-80-87415-42-9.

JÜRGENSON, E. - HASS, H. - MAASIKAMÄE, S. 2010. The Impact of Land Fund Characteristics on the Land Reform Results in Estonian Rural Municipalities. In Vagos, vol. 86, 2010, no. 86 (39), pp. 65-70. Available at: http://www.lzuu.lt/vagos/lt/32032.

KORTHALS, A. W. - BONG, I. S. 2011. Promoting Rural Development through the Use of Land Consolidation: The Case of Korea. In International Planning Studies, vol. 16, 2011, no. 2, pp. 151-167. DOI http://dx.doi.org/10.1080/13563475.2011.561060.

LEITMANOVÁ, M. 2013. Creation of data base for the implementation of information system of land consolidation projects : PhD thesis. Nitra : SUA, 2013. 111. p.

MUCHOVÁ, Z. - LEITMANOVÁ, M. - PETROVIČ, F. 2016. Possibilities of optimal land use as a consequence of lessons learned from land consolidation projects (Slovakia). In Ecological Engineering, vol. 90, 2016, pp. 294-306. doi:10.1016/j.ecoleng.2016.01.018.

MUCHOVÁ, Z. - VANEK, J. - HALAJ, P. - HRNČIAROVÁ, T. - KONC, L. - RAŠKOVIČ, V. - STREĎANSKÁ, A. - ŠIMONIDES, I. - VAŠEK, A. 2009. Methodical standards for the design of land consolidation. $1^{\text {st }}$ ed., Nitra : Garmond, 2009. p. 379. ISBN 978-8-552-0267-9.

MZe. 2015. Cross Compliance. Farmer guide for 2015. Prague : The Ministry of Agriculture of the Czech Republic, 2015. 38 p. ISBN 978-80-7434-208-0.

PAŠAKARNIS, G. - MALIENE, V. 2010. Towards sustainable rural development in Central and Eastern Europe: Applying land consolidation. In Land Use Policy, vol. 27, 2010, no. 2, pp. 545-549. doi:10.1016/j.landusepol.2009.07.008.

SKLENIČKA, P. 2006. Applying evaluation criteria for the land consolidation effect to three contrasting study areas in the Czech Republic. In Land Use Policy, vol. 23, 2006, no. 4, pp. 502-510.

ŠINKA, K. - KONC, L. 2014. The calculation of topographical factor using USLE2D and GIS. In Veda mladých, Krakow : SUA, 2014, pp. 206-219. ISBN 9788055211893.

TARASOVIČOVÁ, Z. - SAKSA, M. - BLAŽÍK, T. - FALŤAN, V. 2013. Changes in Agricultural Land Use in the Context of Ongoing Transformational Processes in Slovakia. In Agriculture, vol. 59, 2013, no. 2, pp. 49-64. doi:10.2478/agri-2013-0005.

T.G.M. Water Research Institute. 2009. Methodology of mapping flood risk. Brno : T. G. Masaryk Water Research Institute, 2009, 75 p.

VAŠEK, A. 2014. Land consolidation yesterday, today and tomorrow in Slovakia. In Almanac of lectures from IX. international conference about Land registry. Časta - Papiernicka : Slovak Society of Surveyors and Cartographers, 2014, pp. 25-43.

VITIKAINEN, A. 2004. An Overview of Land Consolidation in Europe. In Nordic Journal of Surveying and Real Estate Research, vol. 1, 2004, pp. 25-44. 